\title{
Gelastic attack in a child with moyamoya disease
}

Hime Suzuki, MD,* Takeshi Mikami, MD, PhD, * Rei Enatsu, MD, PhD, Aya Kanno, MD, Yasuhiro Takahashi, MD, and Nobuhiro Mikuni, MD, PhD

Neurology ${ }^{\circledR}$ 2018;91:141-142. doi:10.1212/WNL.0000000000005826

\section{Correspondence}

Dr. Mikami

tmikami@sapmed.ac.jp

Figure 1 Preoperative radiologic findings

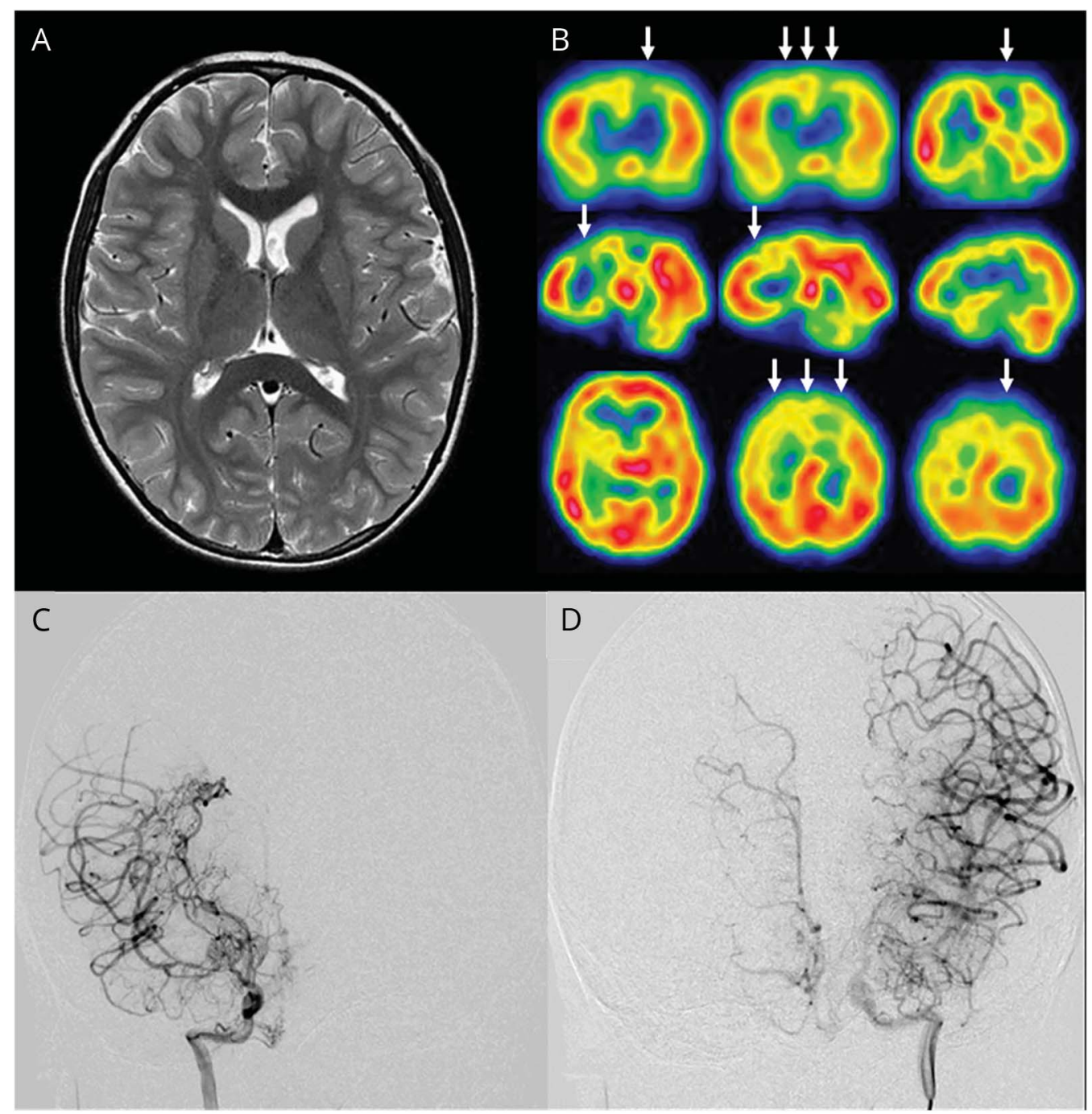

(A) T2-weighted axial MRI shows no lesions. (B) Interictal ${ }^{123}$ I-IMP SPECT shows decreased cerebral blood flow in multiple areas including the frontal lobe and cingulate gyrus; arrows show the areas of decreased uptake. (C) Right internal carotid angiography and (D) left internal carotid angiography show stenoocclusive changes at the terminal portion of the bilateral internal carotid artery and moyamoya vessels.

A 7-year-old girl presented with paroxysms of transient laughter accompanied by right limb weakness, followed by crying. She was diagnosed with moyamoya disease (figure 1). Interictal ${ }^{123}$ I-IMP-SPECT showed decreased cerebral blood flow in multiple areas including the frontal lobe
MORE ONLINE

Video

*These authors contributed equally to this work.

From the Department of Neurosurgery, Sapporo Medical University, Japan.

Go to Neurology.org/N for full disclosures. Funding information and disclosures deemed relevant by the authors, if any, are provided at the end of the article. 

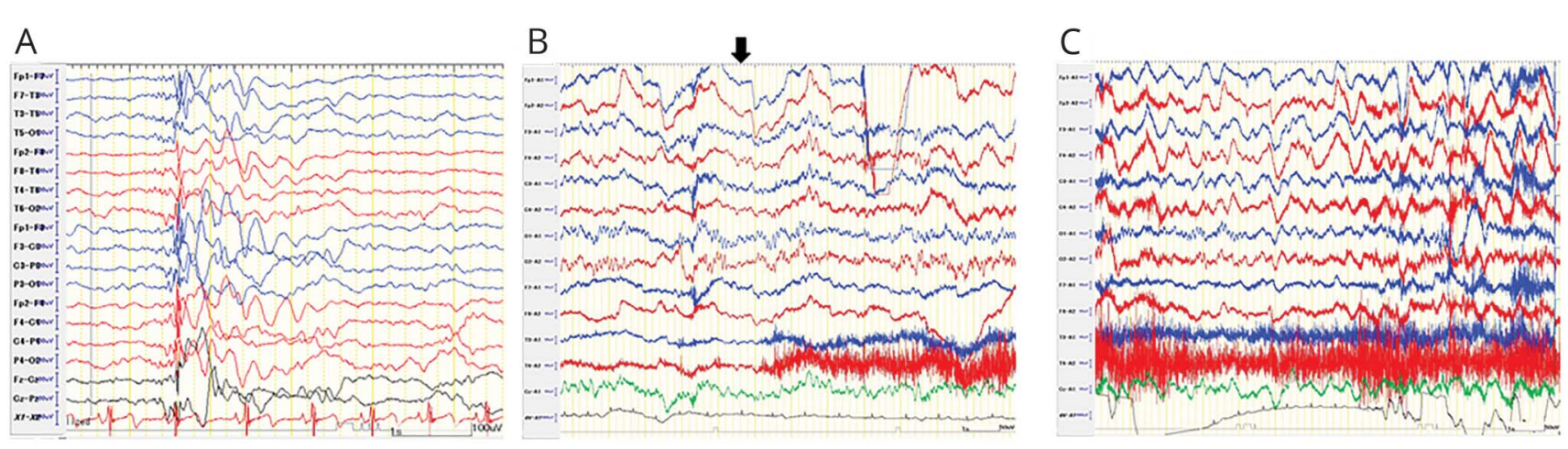

(A) Interictal EEG shows generalized spike-and-slow-wave complexes at a frequency of once per hour. (B, C) Ictal EEG during an attack induced by hyperventilation. (B) Arrow shows the onset of a gelastic attack associated with a prominent muscle artifact, then generalized slowing was recognized 10 minutes later (C). No epileptiform discharge was observed.

and cingulate gyrus (figure 1). All the paroxysms of laughter occurred without unconsciousness and appeared only after hyperventilation during crying (video). EEG revealed no epileptiform discharge in the ictal state (figure 2). After bilateral revascularization, the paroxysms did not reappear. These attacks had behavioral features consistent with ischemia or epilepsy, the former being more likely. ${ }^{1,2}$

\section{Author contributions}

Hime Suzuki: acquisition of data, analysis and interpretation of data, writing. Takeshi Mikami: acquisition of data, analysis and interpretation of data, supervision. Rei Enatsu: analysis of data. Aya Kanno: acquisition and analysis of data.
Yasuhiro Takahashi: acquisition of data. Nobuhiro Mikuni: supervision.

\section{Study funding}

No targeted funding reported.

\section{Disclosure}

The authors report no disclosures relevant to the manuscript. Go to Neurology.org/N for full disclosures.

\section{References}

1. Arroyo S, Lesser RP, Gordon B, et al. Mirth, laughter and gelastic seizures. Brain 1993; $116(\mathrm{pt} \mathrm{4):757-780.}$

2. Im SH, Oh CW, Kwon OK, Cho BK, Chung YS, Han DH. Involuntary movement induced by cerebral ischemia: pathogenesis and surgical outcome. J Neurosurg 2004;100:877-882.

\section{Disputes \& Debates: Rapid online correspondence}

The editors encourage comments on recent articles through Disputes \& Debates:

Access an article at Neurology.org/N and click on "COMMENT" beneath the article header. Responses will be posted within 3 business days.

Before submitting a comment to Disputes \& Debates, remember the following:

- Disputes \& Debates is restricted to comments about studies published in Neurology within the last eight weeks

- Read previously posted comments; redundant comments will not be posted

- Your submission must be 200 words or less and have a maximum of five references; reference one must be the article on which you are commenting

- You can include a maximum of five authors (including yourself) 


\title{
Neurology
}

\author{
Gelastic attack in a child with moyamoya disease \\ Hime Suzuki, Takeshi Mikami, Rei Enatsu, et al. \\ Neurology 2018;91;141-142 \\ DOI 10.1212/WNL.0000000000005826
}

This information is current as of July 16, 2018

$\begin{array}{ll}\begin{array}{l}\text { Updated Information \& } \\ \text { Services }\end{array} & \begin{array}{l}\text { including high resolution figures, can be found at: } \\ \text { http://n.neurology.org/content/91/3/141.full }\end{array} \\ \text { References } & \text { This article cites } 2 \text { articles, } 0 \text { of which you can access for free at: } \\ & \text { http://n.neurology.org/content/91/3/141.full\#ref-list-1 } \\ \text { Subspecialty Collections } & \text { This article, along with others on similar topics, appears in the } \\ & \text { following collection(s): } \\ & \text { All Cerebrovascular disease/Stroke } \\ & \text { http://n.neurology.org/cgi/collection/all_cerebrovascular_disease_strok } \\ & \text { e } \\ & \text { All Clinical Neurology } \\ & \text { http://n.neurology.org/cgi/collection/all_clinical_neurology } \\ & \text { All Epilepsy/Seizures } \\ & \text { http://n.neurology.org/cgi/collection/all_epilepsy_seizures } \\ & \text { Childhood stroke } \\ \text { http://n.neurology.org/cgi/collection/childhood_stroke } & \\ & \text { Information about reproducing this article in parts (figures,tables) or in } \\ & \text { its entirety can be found online at: } \\ & \text { http://www.neurology.org/about/about_the_journal\#permissions } \\ & \text { Information about ordering reprints can be found online: } \\ \text { Pttp://n.neurology.org/subscribers/advertise }\end{array}$

Neurology ${ }^{\circledR}$ is the official journal of the American Academy of Neurology. Published continuously since 1951, it is now a weekly with 48 issues per year. Copyright (O 2018 American Academy of Neurology. All rights reserved. Print ISSN: 0028-3878. Online ISSN: 1526-632X.

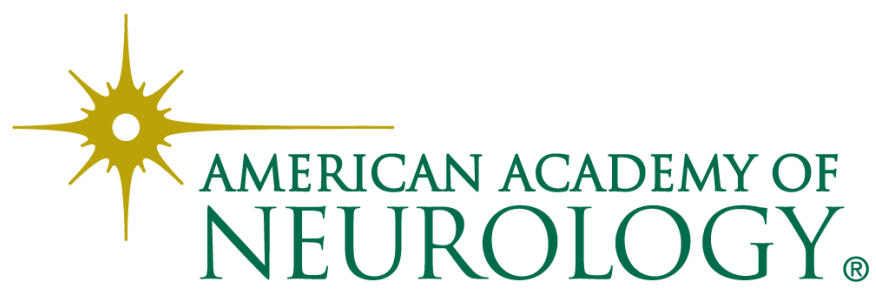

